\title{
FAKTOR YANG MEMPENGARUHI VARISES VENA TUNGKAI BAWAH (VVTB) PADA GURU SEKOLAH DASAR (SD) DI DESA SECURAI SELATAN KECAMATAN BABALAN KABUPATEN LANGKAT TAHUN 2019
}

\author{
Riyan Sabputra', Santy Deasy Siregar ${ }^{2}$, Rapael Ginting ${ }^{3}$ \\ ${ }^{1}$ Universitas Prima Indonesia Jl Sekip Simp. Sikambing, Medan, Indonesia \\ ${ }^{2}$ Universitas Prima Indonesia \\ ${ }^{3}$ Universitas Prima Indonesia \\ Email: riyansabputra94@gmail.com \\ DOI : https://doi.org/10.35451/jkg.v2i1.226
}

\begin{abstract}
Varicose veins of the lower limb (VVTB) abnormalities of blood vessels in the lower extremities. The prevalence of VVTB in Europe is around $50 \%$ of the adult population. The incidence of varicose veins in Indonesia is $25 \%$ to $30 \%$ in women and $10 \%$ to $20 \%$ in men. Based on a preliminary survey in Desa Securai Selatan, Babalan Subdistrict, Langkat Regency, out of 10 people there were 7 people suffering from VVTB. Therefore, the authors want to find out the factors that affect Varicose Veins of Lower Legs (VVTB) in Primary School (SD) teachers in Securai Selatan Village, Babalan Subdistrict, Langkat Regency in 2019. Types of analytical research with cross sectional approach. The population is Elementary School (SD) teachers in Securai Selatan Village, Babalan Subdistrict, Langkat Regency as many as 35 female teachers consisting of SD Alur Rejo having 19 teachers, SD Batang Rejo having 6 teachers and SD Sendayan having 10 teachers. The sample in this study using total sampling. Data analysis was performed with univariate and bivariate analysis with chi-square test. The results of the study were elementary school teachers based on the long standing majority of the categories that did not last long, namely 19 people (54.3\%), the majority age category $\geq 30$ years was 28 people $(80.0 \%)$, majority education in $S 1$ category is 33 people $(94.3 \%)$, obesity in the majority category is not obese that is 18 people (51.4\%), the use of high heels majority of the categories do not wear high heels that is 25 people $(71,4 \%)$, the majority of VVTB categories were not VVTB, namely 28 people (80.0\%). The conclusion is the influence of long standing factors, age, obesity and the use of high heels on VVTB in elementary school teachers in Securai Selatan Village, Babalan Subdistrict, Langkat Regency in 2019. The research suggestion is that teachers are expected to prevent VVTB by minimizing the work of teachers who are dominated by standing length of time in teaching and limiting the use of high heels to less than or equal to $5 \mathrm{~cm}$ because the use of shoes more than $5 \mathrm{~cm}$ is easier for potential varicose veins in the lower limbs
\end{abstract}

Keywords: Factors, Varicose Veins of Lower Legs (VVTB) 


\section{Pendahuluan}

Varises vena tungkai bawah (VVTB) adalah manifestasi kutaneus dari insufisiensi vena kronik pada ekstremitas bawah atau kelainan pembuluh darah. Penyakit ini merupakan yang penyakit yang sering ditemui di klinik dan masih dianggap sebagai penyakit biasa dan tidak perlu di lakukan pengobatan (Beale, 2012).Wanita adalah penderita utama untuk penyakit VVTB dan $50 \%$ terjadi pada orang dewasa. (Carina, 2012).

Badan survei di Amerika Serikat mencatat $59 \%$ wanita menggunakan sepatu hak tinggi kurang lebih satu sampai delapan jam perharinya. Pemakaian sepatu hak tinggi dapat menyebabkan masalah pada pembuluh darah. Artinya, tendon Akhiles yang berada di tumit belakang dan otot betis terus-menerus dalam keadaan tegang. Pembuluh darah tertekan, terjadi bendungan dan akhirnya mengakibatkan varises (Bretha, 2013)

Angka kejadian varises di Indonesia saat ini diperkirakan sekitar 25\% sampai $30 \%$ pada wanita dan $10 \%$ sampai $20 \%$ pada pria (Suwignyo, 2017)

Di negara-negara maju pasien dengan keluhan varises datang ke pelayanan medis bukan hanya untuk pengobatan varises melainkan untuk alasan memperbaiki penampilan yang ditimbulkan varises. Gejala-gejala yang dapat muncul dari penyakit ini adalah nyeri, sakit, gatal, rasa berat, kram, komplikasi lainnya, dan penampilan yang kurang baik (Putri, 2014).

Beberapa tahun terakhir VVTB mulai mendapat perhatian dari berbagai kalangan hal ini karena VVTB dapat menimbulkan gejala yang mengganggu mulai dari rasa berat pada tungkai, rasa nyeri/sensasi terbakar, kejang otot betis serta pembengkaan ringan pada kaki (Budi, 2013).

Faktor pekerjaan yang memaksa seseorang untuk berdiri dalam waktu yang lama juga merupakan faktor dari varises. posisi berdiri tanpa kontraksi otot dapat mengakibatkan penimbunan darah di tungkai sehingga vena tersebut akan melebar (Feby, 2012).

Penelitian Carina tahun 2012 menyatakan riwayat keluarga, overweight/obesitas, dan berdiri lama merupakan faktor yang berhubungan dengan terjadinya VVTB pada wanita usia produktif.

Desa Securai Selatan Kecamatan Babalan Kabupaten Langkat memiliki 3 (tiga) Sekolah Dasar (SD) yaitu SD Alur Rejo, SD Batang Rejo dan SD Sendayan. Berdasarkan survey pendahuluan yang peneliti lakukan pada guru di Sekolah Dasar (SD) di Desa Securai Selatan Kecamatan Babalan Kabupaten Langkat bahwa dari 10 orang terdapat 7 orang yang menderita Varises Vena Tungkai Bawah (VVTB). Dari 7 orang tersebut terdapat 3 orang mengeluh nyeri pada kaki pada saat berdiri mengajar, 2 orang mempunyai usia $\geq 30$ tahun, 1 orang mempunyai berat badan obesitas serta 1 orang menggunakan sepatu hak tinggi selama mengajar. Berdasarkan latar belakang, penulis tertarik meneliti tentang faktor yang mempengaruhi Varises Vena Tungkai Bawah (VVTB) pada guru Sekolah Dasar (SD) di Desa Securai Selatan Kecamatan Babalan Kabupaten Langkat Tahun 2019.

\section{METODE PENELITIAN}

Desain penelitian yang digunakan dalam penelitian ini adalah penelitian survei yang mengunakan deskriptif analitik dengan desain cross-sectional study. 
Alasan memakai desain cross-sectional study karena ingin mengukur variabelvariabelnya dalam waktu yang bersamaan. Tujuannya adalah untuk mengetahui faktor yang mempengaruhi Varises Vena Tungkai Bawah (VVTB) pada guru Sekolah Dasar (SD) di Desa Securai Selatan Kecamatan Babalan Kabupaten Langkat Tahun 2019.

Populasi adalah sekelompok subjek yang menjadi objek atau sasaran penelitian. (Notoadmodjo, 2014) Adapun populasi dalam penelitian ini adalahguru Sekolah Dasar (SD) di Desa Securai Selatan Kecamatan Babalan Kabupaten Langkat sebanyak 35 guru perempuan terdiri dari SD Alur Rejo memiliki 19 guru, SD Batang Rejo memiliki 6 guru dan SD

\section{HASIL PENELITIAN}

\section{Analisis Bivariat}

Tabel 1

Pengaruh Faktor Berdiri Lama, Usia, Obesitas, dan Penggunaan Sepatu Hak Tinggi Terhadap Varises Vena Tungkai Bawah (VVTB) Pada Guru Sekolah Dasar (SD) di Desa Securai Selatan Kecamatan Babalan Kabupaten Langkat Tahun 2019

\begin{tabular}{|c|c|c|c|c|c|c|c|}
\hline \multirow{3}{*}{ Berdiri Lama } & \multicolumn{4}{|c|}{$\begin{array}{c}\text { Varises Vena Tungkai Bawah } \\
\text { (VVTB) }\end{array}$} & \multirow{2}{*}{\multicolumn{2}{|c|}{ Jumlah }} & \multirow[t]{3}{*}{ p value } \\
\hline & \multicolumn{2}{|c|}{ VVTB } & \multicolumn{2}{|c|}{ Tidak VVTB } & & & \\
\hline & $\mathbf{f}$ & $\%$ & $\mathbf{f}$ & $\%$ & $\mathbf{f}$ & $\%$ & \\
\hline Berdiri lama & 7 & 43,8 & 9 & 56,3 & 16 & 100 & \\
\hline Tidak berdiri lama & 0 & 0 & 19 & 100 & 19 & 100 & 0,002 \\
\hline \multicolumn{8}{|l|}{ Usia } \\
\hline$\geq 30$ tahun & 2 & 7,1 & 26 & 92,9 & 28 & 100 & 0,001 \\
\hline$<30$ tahun & 5 & 71,4 & 2 & 28,6 & 7 & 100 & \\
\hline \multicolumn{8}{|l|}{ Obesitas } \\
\hline Obesitas & 7 & 41,2 & 10 & 58,8 & 17 & 100 & 0,003 \\
\hline Tidak obesitas & 0 & 0 & 18 & 100 & 18 & 100 & \\
\hline \multicolumn{8}{|c|}{$\begin{array}{c}\text { Penggunaan Sepatu Hak } \\
\text { Tinggi }\end{array}$} \\
\hline $\begin{array}{l}\text { Memakai sepatu hak } \\
\text { tinggi }\end{array}$ & 6 & 60,0 & 4 & 40,0 & 10 & 100 & 0,001 \\
\hline $\begin{array}{l}\text { Tidak memakai } \\
\text { sepatu hak tinggi }\end{array}$ & 1 & 4,0 & 24 & 96,0 & 25 & 100 & \\
\hline
\end{tabular}

Berdasarkan tabel 1. diatas bahwa berdiri lama pada guru Sekolah Dasar (SD)
Sendayan memiliki 10 guru. Sampel adalah sebagian dari jumlah dan karakteristik yang dimiliki oleh populasi.(Notoadmodjo, 2014). Sampel dalam penelitian ini adalah 35 guru perempuandi Desa Securai Selatan Kecamatan Babalan Kabupaten Langkatpada bulan Maret 2019.Teknik pengambilan sampel dalam penelitan ini menggunakan total population.

Penelitian ini dilakukan pada bulan Juli 2019. Pengumpulan data dalam penelitian dilakukan dengan wawancara dengan menggunakan alat bantu kuesioner. Uji Satistik pada analisis data menggunakan Uji Chi Square $\left(\mathrm{X}^{2}\right)$ dengan tingkat kepercayaan $95 \%$ menggunakan program SPSS. 
dan tidak VVTB yaitu 19 orang (100\%) sedangkan minoritas berdiri lama yaitu 16 orang $(100 \%)$ dengan kategori VVTB yaitu 7 orang $(43,8 \%)$ dan tidak VVTB yaitu 9 orang $(56,3 \%)$. Berdasarkan hasil uji chi square dengan nilai signifikansi yaitu 0,002 $<0,05$, maka Ho ditolak dan Ha diterima. Kesimpulannya ada pengaruh faktor berdiri lama terhadap Varises Vena Tungkai Bawah (VVTB) pada guru Sekolah Dasar (SD) di Desa Securai Selatan Kecamatan Babalan Kabupaten Langkat Tahun 2019.

Berdasarkan tabel 1. diatas bahwa usia pada guru Sekolah Dasar (SD) mayoritas $\geq 30$ tahun yaitu 28 orang (100\%) dengan kategori VVTB yaitu 2 orang $(74,3 \%)$ dan tidak VVTB yaitu 26 orang $(92,9 \%)$ sedangkan minoritas < 30 tahun yaitu 7 orang (100\%) dengan kategori VVTB yaitu 5 orang $(71,4 \%)$ dan tidak VVTB yaitu 2 orang $(28,6 \%)$. Berdasarkan hasil uji chi square dengan nilai signifikansi yaitu 0,001 $<0,05$, maka Ho ditolak dan Ha diterima. Kesimpulannya ada pengaruh faktor usia terhadap Varises Vena Tungkai Bawah (VVTB) pada guru Sekolah Dasar (SD) di Desa Securai Selatan Kecamatan Babalan Kabupaten Langkat Tahun 2019

Berdasarkan tabel 1. diatas bahwa obesitas pada guru Sekolah Dasar (SD) mayoritas tidak obesitas yaitu 18 orang (100\%) dengan kategori VVTB tidak ada dan tidak VVTB yaitu 18 orang (100\%) sedangkan minoritas obesitas yaitu 17 orang $(100 \%)$ kategori VVTB yaitu 7 orang $(41,2 \%)$ dan tidak VVTB yaitu 10 orang $(58,8 \%)$. Berdasarkan hasil uji chi square dengan nilai signifikansi yaitu 0,003 < 0,05, maka Ho ditolak dan Ha diterima. Kesimpulannya ada pengaruh faktor obesitas terhadap Varises Vena Tungkai Bawah (VVTB) pada guru Sekolah Dasar (SD) di Desa Securai Selatan Kecamatan Babalan Kabupaten Langkat Tahun 2019.
Berdasarkan tabel 1. diatas bahwa penggunaan sepatu hak tinggi pada guru Sekolah Dasar (SD) mayoritas tidak memakai sepatu hak tinggi yaitu 25 orang (100\%) dengan kategori VVTB yaitu 1 orang $(4,0 \%)$ dan tidak VVTB yaitu 24 orang $(96,0 \%)$ sedangkan minoritas memakai sepatu hak tinggi yaitu 10 orang (100\%) dengan kategori VVTB yaitu 6 orang $(60,0 \%)$ dan tidak VVTB yaitu 4 orang $(40,0 \%)$. Berdasarkan hasil uji chi square dengan nilai signifikansi yaitu 0,001 $<0,05$, maka Ho ditolak dan Ha diterima. Kesimpulannya ada pengaruh faktor penggunaan sepatu hak tinggi terhadap Varises Vena Tungkai Bawah (VVTB) pada guru Sekolah Dasar (SD) di Desa Securai Selatan Kecamatan Babalan Kabupaten Langkat Tahun 2019.

\section{PEMBAHASAN}

\section{Pengaruh Faktor Berdiri Lama Terhadap Varises Vena Tungkai Bawah (VVTB) Pada Guru Sekolah Dasar (SD)}

Berdasarkan hasil uji chi square dengan nilai signifikansi yaitu 0,002 < 0,05, maka ada pengaruh faktor berdiri lama terhadap Varises Vena Tungkai Bawah (VVTB) pada guru Sekolah Dasar (SD) di Desa Securai Selatan Kecamatan Babalan Kabupaten Langkat Tahun 2019.

Penelitian Carina tahun 2012 mengatakan bahwa terdapat hubungan bermakna antara berdiri lama dengan terjadinya VVTB $(p<0,001)$. Posisi berdiri lama saat bekerja menambah tekanan pada vena di tungkai bawah. Ketika seseorang berdiri diam selama jangka waktu yang lama, dinding vena tidak dapat menahan tekanan hidrostatik akibat tekanan tinggi lokal dan kurangnya tindakan pemompaan otot kaki. Sebagai hasil, katup vena menjadi tidak kompeten dan darah vena secara bertahap terakumulasi di kaki sehingga membentuk varises 
Penelitian Suwignyo tahun 2017 mengatakan bahwa sebagian besar yang berdiri lama > 3 jam menderita varises vena tungkai bawah sebanyak 49 sampel (66\%) dan yang tidak varises vena tungkai bawah sebanyak 10 sampel (14\%).Sedangkan yang tidak berdiri lama $<3$ jam menderita varises vena tungkai bawah sebanyak sebanyak 7 sampel $(9 \%)$ dan yang tidak varises vena tungkai bawah sebanyak 8 sampel ( $11 \%)$

Berdiri terlalu lama membuat kaki terlalu berat menahan tubuh dan memperparah beban kerja pembuluh darah vena dalam mengalirkan darah. Bila pekerjaan yang mengharuskan banyak berdiri, maka usahakan untuk tidak berdiri dengan posisi statis (diam), tetapi tetap bergerak. Berjalan di tempat agar otot tungkai dapat terus bekerja memompa darah ke jantung merupakan salah satu contoh posisi untuk mengurangi terjadinya varises (Mansjoer, 2015).

Asumsi peneliti bahwa ada pengaruh faktor berdiri lama terhadap Varises Vena Tungkai Bawah (VVTB) pada guru Sekolah Dasar (SD). Hal ini disebabkan karena berdiri lama mempengaruhi terjadinya VVTB. Berdasarkan dari hasil penelitian mayoritas responden yang tidak berdiri lama kemungkinan tidak terjadi VVTB sedangkan responden yang berdiri lama kemungkinan dapat terjadi VVTB. Berdiri lama mempengaruhi angka kejadian varises vena tungkai bawah karena posisi berdiri yang lama akan menyebabkan tekanan darah pada vena tungkai bawah meningkat sehingga lama kelamaan akan meningkatkan pelebaran pembuluh darah vena yang pada akhirnya menyebabkan insufisiensi, kondisi di mana dinding atau katup pembuluh darah balik (vena) di tungkai tidak berkerja secara efektif sehingga darah dari tungkai sulit dipompa kembali ke jantung. Peningkatan tekanan hidrostatik kronis pada pekerjaan yang membutuhkan berdiri lama juga berperan dalam menimbulkan VVTB. Pada posisi tersebut tekanan vena menjadi 10 kali lebih besar, sehingga vena akan teregang di luar batas kemampuan elastisitasnya sehingga terjadi inkompetensi pada katup.

\section{Pengaruh Faktor Usia Terhadap Varises Vena Tungkai Bawah (VVTB) Pada Guru Sekolah Dasar (SD)}

Berdasarkan hasil uji chi square dengan nilai signifikansi yaitu 0,001 < 0,05, maka pengaruh faktor usia terhadap Varises Vena Tungkai Bawah (VVTB) pada guru Sekolah Dasar (SD) di Desa Securai Selatan Kecamatan Babalan Kabupaten Langkat Tahun 2019

Penelitian Carina tahun 2012 mengatakan bahwa berusia lebih dari 30 tahun lebih berisiko 1,5 kali untuk terjadi VVTB dibandingkan yang berumur kurang dari atau sama dengan 30 tahun $(O R=1,6$; $95 \% \mathrm{CI}=0,5 \mathrm{~s} / \mathrm{d} 4,8)$. Hal ini sesuai dengan teori yaitu dengan semakin bertambahnya usia, dinding vena menjadi lemah karena lamina elastis menjadi tipis dan atrofik bersama dengan adanya degenerasi otot polos.

Asumsi peneliti bahwa ada pengaruh faktor usia terhadap Varises Vena Tungkai Bawah (VVTB) pada guru Sekolah Dasar (SD). Seiring bertambahnya usia insiden VVTB akan meningkat. Dinding vena menjadi lemah karena lamina elastis menjadi tipis dan atrofik bersama dengan adanya degenerasi otot polos. Disamping itu akan terdapat atrofi otot betis sehingga tonus otot menurun. Semakin tinggi usia semakin besar kemungkinan terjadinya Varises Vena Tungkai Bawah (VVTB) namun terjadinya VVTB dapat disebabkan oleh faktor lain yang menjadi faktor indikasi terjadinya VVTB.

Pengaruh Faktor Obesitas Terhadap Varises Vena Tungkai Bawah (VVTB) Pada Guru Sekolah Dasar (SD) 
Berdasarkan hasil uji chi square dengan nilai signifikansi yaitu $0,003<$ 0,05 , maka ada pengaruh faktor obesitas terhadap Varises Vena Tungkai Bawah (VVTB) pada guru Sekolah Dasar (SD) di Desa Securai Selatan Kecamatan Babalan Kabupaten Langkat Tahun 2019.

Penelitian Carina tahun 2012 mengatakan bahwa obesitas memberikan hubungan yang bermakna dengan kejadian VVTB $(p<0,001)$, hal tersebut menunjukkan bahwa subyek dengan Indeks Massa Tubuh (IMT) > 23 mempunyai risiko timbulnya VVTB lebih besar dibandingkan subyek dengan IMT $\leq$ 23 dan bermakna secara statistik. Obesitas memiliki pengaruh terhadap timbulnya VVTB, hal ini disebabkan oleh beban tungkai bawah yang lebih berat dan tekanan darah vena di tungkai juga meningkat

Asumsi peneliti bahwa ada pengaruh faktor obesitas terhadap Varises Vena Tungkai Bawah (VVTB) pada guru Sekolah Dasar (SD). Berdasarkan hasil penelitian bahwa sebagian besar responden yang tidak obesitas kemungkinan tidak mengalami VVTB. Obesitas memiliki pengaruh terhadap timbulnya VVTB, hal ini disebabkan oleh beban tungkai bawah yang lebih berat dan tekanan darah vena di tungkai juga meningkat. Resiko terkena VVTB lebih tinggi pada seseorang dengan BMI (Body Mass Index) yang tinggi dibanding seseorang dengan usia yang sama dengan berat badan sesuai. Terdapat hipotesis yang menyatakan hal ini dihubungkan dengan tekanan hidrostatik yang meningkat akibat peningkatan volume darah serta kecenderungan jeleknya struktur penyangga vena.

Pengaruh Faktor Penggunaan Sepatu Hak Tinggi Terhadap Varises Vena Tungkai Bawah (VVTB) Pada Guru Sekolah Dasar (SD)
Berdasarkan hasil uji chi square dengan nilai signifikansi yaitu 0,001 < 0,05, maka ada pengaruh faktor penggunaan sepatu hak tinggi terhadap Varises Vena Tungkai Bawah (VVTB) pada guru Sekolah Dasar (SD) di Desa Securai Selatan Kecamatan Babalan Kabupaten Langkat Tahun 2019

Penelitian Suwignyo tahun 2017 mengatakan bahwa sebagian besar yang memakai sepatu hak tinggi $>5 \mathrm{~cm}$ menderita varises vena tungkai bawah sebanyak 52 sampel (70\%), dan yang tidak varises vena tungkai bawah sebanyak 11 sampel (15\%).Sedangkan yang tidak memakai sepatu hak tinggi $<5 \mathrm{~cm}$ menderita varises vena tungkai bawah sebanyak 4 sampel (5\%), dan yang tidak varises vena tungkai bawah sebanyak 7 sampel $(10 \%)$.

Penderita varises biasanya merasakan nyeri dan keram pada kaki, terutama pada saat berdiri maupun saat beraktivitas dan nyeri berkurang jika istirahat. Nyeri ini biasa disebut sebagai claudication intermitten. Pemakaian sepatu hak tinggi yang sering dapat membuat tonus otot melemah sehingga pembuluh darah balik meregang menyebabkan vena kehilangan kelenturannya sehingga vena meregang dan menjadi lebih panjang dan lebih lebar (Bretha, 2013)

Asumsi peneliti bahwa ada pengaruh faktor penggunaan sepatu hak tinggi terhadap Varises Vena Tungkai Bawah (VVTB) pada guru Sekolah Dasar (SD). Berdasarkan hasil penelitian mayoritas responden yang tidak menggunakan sepatu hak tidak kemungkinan tidak terjadinya VVTB yaitu $96 \%$. Penggunaan sepatu hak tinggi mempengaruhi angka kejadian varises vena tungkai bawah, yaitu semakin tinggi sepatu hak tinggi yang digunakan maka kemungkinan mengalami varises vena tungkai bawah lebih tinggi. Hal ini 
dikarenakan ketika seorang perempuan memakai sepatu hak tinggi $(5 \mathrm{~cm}$ atau lebih), kaki tidak mampu menahan beban secara merata, dan sulit menjaga keseimbangan struktur pembuluh darah vena. Sehingga memperberat keadaan dimana tonus otot melemah dan pembuluh darah balik meregang. Ini menyebabkan vena kehilangan kelenturannya sehingga vena meregang menjadi lebih panjang dan lebih lebar. Penggunaan sepatu hak tinggi dapat menyebabkan masalah pada pembuluh darah. Pemakaian sepatu hak tinggi (lebih dari $5 \mathrm{~cm}$ ) memiliki risiko kesehatan. Pemakaian sepatu hak tinggi dapat menyebabkan masalah pada pembuluh darah. Pemakaian sepatu hak tinggi diatas lima sentimeter membuat kaki terus-menerus menjinjit. Artinya, tendon Akhiles yang berada di tumit belakang dan otot betis terus-menerus dalam keadaan tegang.Pembuluh darah tertekan, terjadi bendungan dan akhirnya mengakibatkan varises.Sepatu hak tinggi dapat memperburuk keadaan ini dengan mengubah penyokongan berat badan ke depan dan membelokkan jari ke depan sepatu. Perasaan tidak nyaman oleh pemakaian sepatu hak tinggi didominasi oleh nyeri kaki.Penyempitan arteri juga dapat menurunkan aliran darah ke tungkai yang berperan untuk nyeri.

\section{KESIMPULAN}

Dari hasil penelitian faktor yang mempengaruhi Varises Vena Tungkai Bawah (VVTB) pada guru Sekolah Dasar (SD) di Desa Securai Selatan Kecamatan Babalan Kabupaten Langkat Tahun 2019 maka dapat disimpulkan sebagai berikut: Ada pengaruh faktor berdiri lama, usia, obesitas penggunaan sepatu hak tinggi terhadap Varises Vena Tungkai Bawah (VVTB) pada guru Sekolah Dasar (SD) di Desa Securai Selatan Kecamatan Babalan Kabupaten Langkat Tahun 2019

\section{DAFTAR PUSTAKA}

Anggraeni Janar Wulan, Astriani Rahayu, 2016. Risiko Pemakaian Sepatu Hak Tinggi Bagi Kesehatan Tungkai Bawah. juke.kedokteran.unila.ac.id/index.p $\mathrm{hp} / \mathrm{majority} /$ article/view/1031.

Diakses tanggal 3 November 2018

Arikunto, 2013. Prosedur Penelitian, Suatu Pendekatan Praktik. Jakarta: Rineka Cipta

Arisman, 2013.Obesitas, Diabetes Melitus dan Dislipidemia : Konsep, Teori, dan Penanganan Aplikatif. Jakarta: EGC

Beale. 2012. Asuhan Keperawatan Varises Vena Tungkai Bawah. GCE . Jakarta

Bretha Arih Kitami S. Maha. 2013. Pengaruh Penggunaan Sepatu Hak Tinggi Terhadap Risiko Timbulnya Varises Pada Tungkai Bawah. Jurnal e-Biomedik (eBM), Volume 1, Nomor 3, November 2013. https://ejournal.unsrat.ac.id/index. php/ebiomedik/article/view/3270.

Diakses tanggal 5 September 2018

Budi Tri Akoso, 2013. Bebas Varises. Yogyakarta : Penerbit Kanisius

Carina Adriana, 2012.Faktor-Faktor Yang Berhubungan Dengan Terjadinya Varises Vena Tungkai Bawah Pada Wanita Usia Produktif. eprints.undip.ac.id/37428/1/CARIN A_ADRIANA_G2A008040_LAP_KTI. pdf. Diakses tanggal 4 September 2018.

Corwin, E. J. 2016. Buku Saku Patofisiologi(Nike Budhi S., Terj.). Jakarta:EGC

Departemen Kesehatan RI. 2010. Pedoman Pengukuran dan Pemeriksaan. Jakarta.

Faiz, Omar., Moffat, David., 2014. At A Glance Anatomi. Jakarta: Erlangga

Feby Lia Ariani. 2012.Hubungan Lama Berdiri Dengan Kejadian Varises Pada Perawat diRuang OK Instalasi Bedah Sentral RSUD Arifin Achmad Pekanbaru. https://repository.unri.ac.id/bitstre 
am/handle/.../

FEBY\%20LIA\%20ARIANI.pdf.

Diakses tanggal 2 September 2018.

Grace, Pierge A., 2016. At A Glance IImu Bedah. Jakarta: Erlangga

Guyton AC, 2014. Hall JE. Distensibilitas Vaskular, Serta Fungsi Sistem Vena danArteri; Kegagalan Katup Vena yang Menyebabkan "Varises".Dalam :Rachman, L.Y, Hartanto, H., Novrianti, A., Wulandari, N., editor. BukuAjar Fisiologi Kedokteran.Edisi ke11.Jakarta : EGC,

Krisno, A.M., 2012. Gizi dan Kesehatan. Jakarta.

Kuncoro Adi Pratiknyo, Asih Budiastuti, YL. Aryoko Widodo. 2016. Faktor Resiko Terjadinya Varises Vena Tungkai Bawah (VVTB) Pada Pramuniaga di Kota Semarang.Jurnal Kedokteran Diponegoro. Volume 5, Nomor 1, Januari 2016. https://media.neliti.com/media/.../ 106357-ID-faktor-resikoterjadinya-varises-vena-tungkaibawah. Diakses tanggal 2 September 2018.

Mansjoer, A. 2015. Kapita Selekta Kedokteran 1. Jakarta: EGC

Notoatmodjo S, 2014. Metode Penelitian Kesehatan. Jakarta: Rineka Cipta

Putri Satriani Agustina. 2014. Hubungan Masa Kerja Dengan Terjadinya Varises Tungkai Bawah Pada Pengemudi BusdiTerminal Tirtonadi. eprints.ums.ac.id/30764/9/NASKA H_PBLIKASI.pdf. Diakses tanggal 6 September 2018.
Sjamsuhidajat, R. dan De Jong W. 2015. Buku Ajar Ilmu Bedah. Jakarta: EGC.

Suparlan. 2016. Menjadi Guru Efektif. Hikayat Publishing, Jogjakarta
Suparlan, 2014. Mencerdaskan Kehidupan Bangsa, Dari Konsepsi Sampai Implementasi,Grafindo Persada, Jakarta

Supariasa, D.N., Bachyar, B., dan Ibnu, F., 2013.Penilaian Status Gizi. Jakarta :EGC.

Suwignyo, Azhari, Esti Ana. 2017.Hubungan Penggunaan Sepatu Hak Tinggi dan Berdiri Lama Dengan Kejadian Varises Pada SPG diPlaza Mulia. husadamahakam.poltekkeskaltim.ac.id/ojs/index.php/Home/ar ticle/download/.../121/. Diakses tanggal 2 September 2018.

Tarwaka, 2016. Keselamatan dan Kesehatan Kerja. Manajemen dan implementasi K3 di Tempat Kerja. Surakarta: Harapan Press

Oemar Hamalik. 2014. Pendidikan Guru: Berdasarkan Pendekatan Kompetensi, Jakarta: PT Bumi Aksara

Yuwono, Hendro S., 2015. Ilmu Bedah Vaskular. Bandung : Refika Aditama. 